\title{
Effect of Reinforcing Rolling on the Surface Properties of Products Made of Heat-Resistant Alloys
}

\author{
A. Shiryaev ${ }^{1}$, N. Vinokurov ${ }^{1}$, V. Trofimov ${ }^{1}$, V. Karmanov ${ }^{1}$, A. Shilyaev ${ }^{2}$ \\ ${ }^{1}$ PNRPU, Perm National Research Polytechnic University, \\ Perm, Russia \\ E-mail: alex.shiryaev.pstu@gmail.com, karmanovs@yandex.ru \\ ${ }^{2}$ LLC "Transet", \\ Saint_Petersburg, Russia \\ E-mail: shilyaev@transetspb.ru
}

Received: June 24, 2018

\begin{abstract}
The process of surface plastic deformation - hardening rolling by a ball is one of the most widespread processes of finishing machining products, allowing to obtain the required mechanical characteristics of the surface of products - hardness, strength, corrosion resistance and wear resistance. The results of the investigation of the effect of rolling modes on the characteristics of the surface layer of samples of high-temperature alloys VZhL14-VM and VZhM-4 are presented: the residual stresses, roughness, microhardness, and the depth of surface crushing. For rolling, a hydrostatic tool installed instead of a rotating assembly on a friction welding machine was used. The analysis of the results shows that the step and the scheme of the tool movement have the most significant influence on the residual stress level, microhardness and roughness. It is shown that, after rolling, the depth of the surface crushing after rolling increases slightly the geometrical dimensions of the samples. The microhardness of the surface is increased by $25-33 \%$, and the microroughness decreases by $2-4$ times. After rolling in the surface layer, compressive residual stresses are recorded, reaching the maximum values in a direction perpendicular to the direction of movement of the tool.
\end{abstract}

Keywords: residual stresses, surface hardening, surface plastic deformation, roughness, microhardness, heat-resistant alloys.

\section{INTRODUCTION}

Typically, the operational properties of the part can be improved by performing heat treatment (HT): quenching, tempering, annealing, etc. Despite their high cost and time costs, maintenance is sometimes not enough to obtain the necessary properties of the material. That is why, in the production of processes of surface plastic deformation (SPD), such as rolling around with a roller or a ball. Due to local plastic deformation, surface topography changes, surface layers are ground and there are compressive residual stresses (RS) [1-4]. Processing of SPD increases fatigue strength, which remains the main cause of the destruction of parts. Therefore, it is important to choose such a SPD technology and processing modes to ensure the required surface quality indicators.

(C) Shiryaev A., Vinokurov N., Trofimov V., Karmanov V., Shilyaev A., 2018 
This technology can be used on cylindrical, flat, complex surfaces, areas of sharp changes in the cross-section, etc. The main limitation of this process is mainly geometric. Despite the complexity of programming processes in the five-axis region, the use of a turning center, $\mathrm{CNC}$ milling machine or robot can cope with this limitation.

In [3-5] the influence of the feed, the depth of penetration, the distance between the tool and the residual stress level for steel 45 is shown. [6] shows the change in microhardness from the rolling force, the diameter of the ball for VT1-1. The procedure for selecting and calculating the parameters of the mode of finishing the SPD is shown in [7]. Depending on the surface force $\mathrm{P}$ of rolling around the ball, it follows that the hardness of $\mathrm{HV}$ increases with increasing $\mathrm{P}$ for steel $12 \mathrm{X} 18 \mathrm{H} 9 \mathrm{~T}$ from the initial 181 to 342 , for the titanium alloy VTZ-1 from 319 to 390 and for the nickel alloy KhN67BMTU from 282 to 412 [8, p. 63]. When studying RS [9], the influence of pressure, feed, velocity, tool dimensions, number of passes, structure and properties of the material was studied.

It was shown in [10] that the parameters of speed, feed, ball pressing force, its radius and number of passes affect the roughness and hardness. The force of pressing the tool affects the depth of the hardened layer. However, with a force $>100 \mathrm{~N}$, the risk of peeling and microcracking of the surface layer increases. The best roughness result is achieved for 3-4 passes.

In [11], for the Ti-6Al-4V material, the optimization problem was investigated-the establishment of maximum residual compressive stresses. To simulate the process, a model of a nonlinear finite element was developed with high accuracy of three-dimensional nonlinearity. According to the results, a large compressive $\mathrm{OH}$ on the surface of the components can be achieved either by reducing the diameter of the ball, or by increasing the number of passes. In addition, to increase the depth of the residual compressive stress, it is necessary to increase the diameter of the ball.

The main parameters affecting the rolling process are the ball diameter, the burning force, the ball speed, the number of tool passes and the initial roughness of the workpiece [12]. Loll et al. [13] studied the effect of machining parameters on the roughness of the structure during deep cold rolling for AISI 1045. Analogous studies of the polishing of rollers were carried out for steel 37 [14] and Al 6061-T6 [15], in which influence of rolling parameters on hardness, roughness and fatigue strength of the part. Taweel and Axir [16] also experimentally studied the influence of the main parameters of the rolling process on the surface microhardness and roughness using the Taguchi method. Klocke et al. [17] investigated the effect of the ball diameter, superposition, pressing force and geometry of a nickel alloy preform on the roughness and the $\mathrm{OH}$ value during ball processing. Fretting strength and RS profile were studied for Ti-6Al-4V [18]. In [19] it was studied the effect of various polishing materials and ball pressing forces on the roughness of a steel product with an initial hardness of 64 HRC. The main producers of the instrument are ECOROLL AG and Lambda Technologies.

A review of the literature shows that the changing parameters on the surface are different: the pressing force and the speed of the tool. Sometimes other factors are introduced, such as the number of passes, the diameter of the ball. The result depends mainly on the combination of various parameters depending on the rigidity of the tool, the properties of the material to be treated, the required processing time, operating conditions and the initial state of the surface layers, and the type of lubricant. 


\section{EXPERIMENTAL PROCEDURE}

\section{Samples and equipment} 4.

Samples: plates $120 \times 48 \times 8 \mathrm{~mm} ; 160 \times 28 \times 14 \mathrm{~mm}$ (Fig. 1). Material: VZhL14-VM, VZhM-

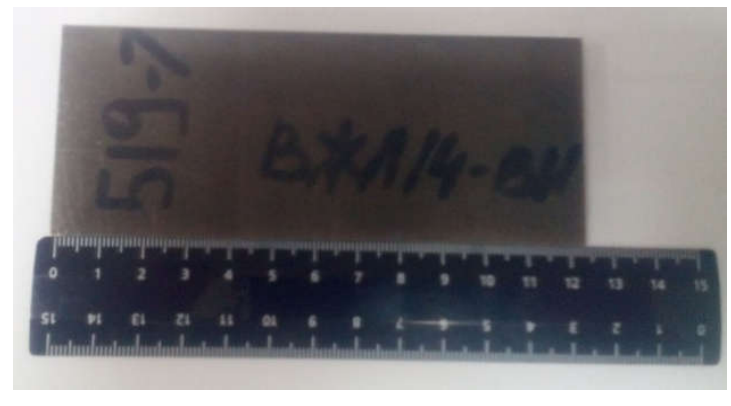

$a$

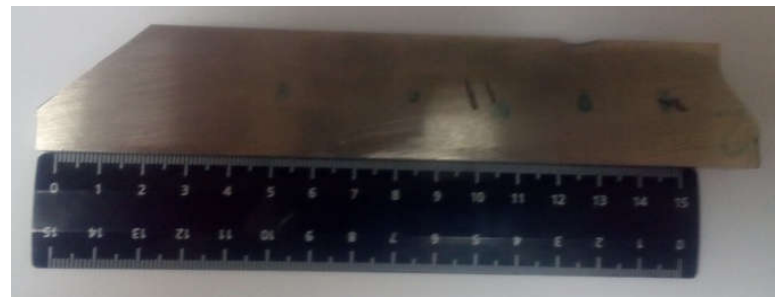

$b$

Figure 1. Samples: $a$-VZhL14-VM (samples No. 1-2); $b$ - VZhM-4 (sample No. 3)

The chemical composition of the high-temperature alloys is shown in Tables 1-2.

Table 1. Chemical composition of alloy VZhL14-VM

\begin{tabular}{c|c|c|c|c|c|c|c|c|c|c|c|c}
\hline $\mathbf{F e}$ & $\mathbf{C}$ & $\mathbf{S i}$ & $\mathbf{M n}$ & $\mathbf{N i}$ & $\mathbf{S}$ & $\mathbf{P}$ & $\mathbf{C r}$ & $\mathbf{C e}$ & $\mathbf{M o}$ & $\mathbf{T i}$ & $\mathbf{A l}$ & $\mathbf{B}$ \\
\hline $8-10$ & $0.05-0.08$ & $\leq 0.4$ & $\leq 0.4$ & $59.1-63.7$ & $\leq 0.01$ & $\leq 0.01$ & $18-20$ & $\leq 0.02$ & $4.5-5.5$ & $2.8-2.9$ & $1.2-1.5$ & $\leq 0.005$ \\
\hline
\end{tabular}

Table 2. Chemical composition of alloy VZhM-4

\begin{tabular}{c|c|c|c|c|c|c|c|c|c|c}
\hline $\mathbf{N i}$ & $\mathbf{P}$ & $\mathbf{L a}$ & $\mathbf{A l}$ & $\mathbf{R e}$ & $\mathbf{C r}$ & $\mathbf{C o}$ & $\mathbf{M o}$ & $\mathbf{R u}$ & $\mathbf{T a}$ & $\mathbf{W}$ \\
\hline 36.7 & 13.3 & 9.3 & 0.7 & 3.3 & 4.7 & 6.7 & 7.7 & 4.7 & 10.2 & 1.5 \\
\hline
\end{tabular}

The residual stress was measured by X-ray diffractometry using a robotic complex XStress $3000 \mathrm{G} 3$ and a collimator with a diameter of $4 \mathrm{~mm}$.

Determination of the depth of the rolled bed was carried out using the coordinate measuring machine CARL ZEISS ACCURA II 9/14/8.

The roughness measurement was carried out using the Mahr MarSurf PS1 device based on $5.6 \mathrm{~mm}$.

The microhardness was measured by the Shimadsu HMV-G21S, a load of $19.61 \mathrm{~N}$.

Samples were measured in the initial state and after rolling in the control points according to the schemes indicated in Fig. 2.

\section{Modes of strengthening processing}

The reinforcing rolling was carried out with a hydrostatic tool HG6-9_SL (K) (Ecoroll) fixed in a special tooling in the friction welding machine I-ISTIR PDS-5, equipped with feedback sensors. Information on the force of the tool pressing is obtained from these sensors. As coolant, I-20 oil was used.

Modes of hardening rolling are given in Tables 3-5.

The mesh rolling was carried out: 1 ) direction $0^{\circ}$ (along the axis of the tool movement); 2) direction $90^{\circ}$ (perpendicular to the movement of the tool) (see Figure 7). 
Shiryaev A., Vinokurov N., Trofimov V., Karmanov V., Shilyaev A.

"Effect of reinforcing rolling on the surface properties of products made of heat-resistant alloys"

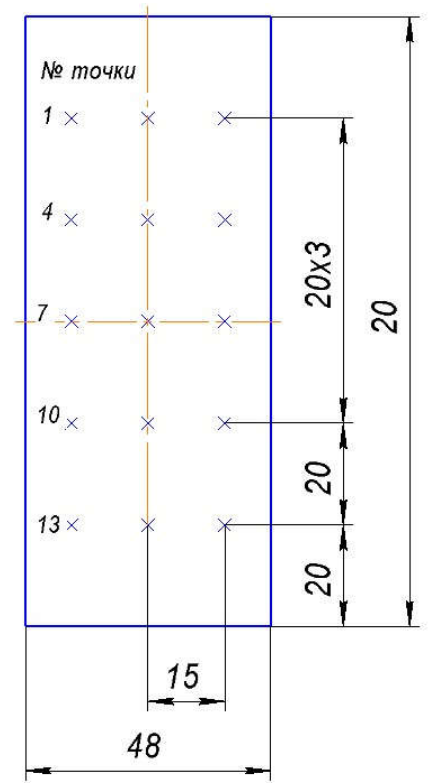

$a$
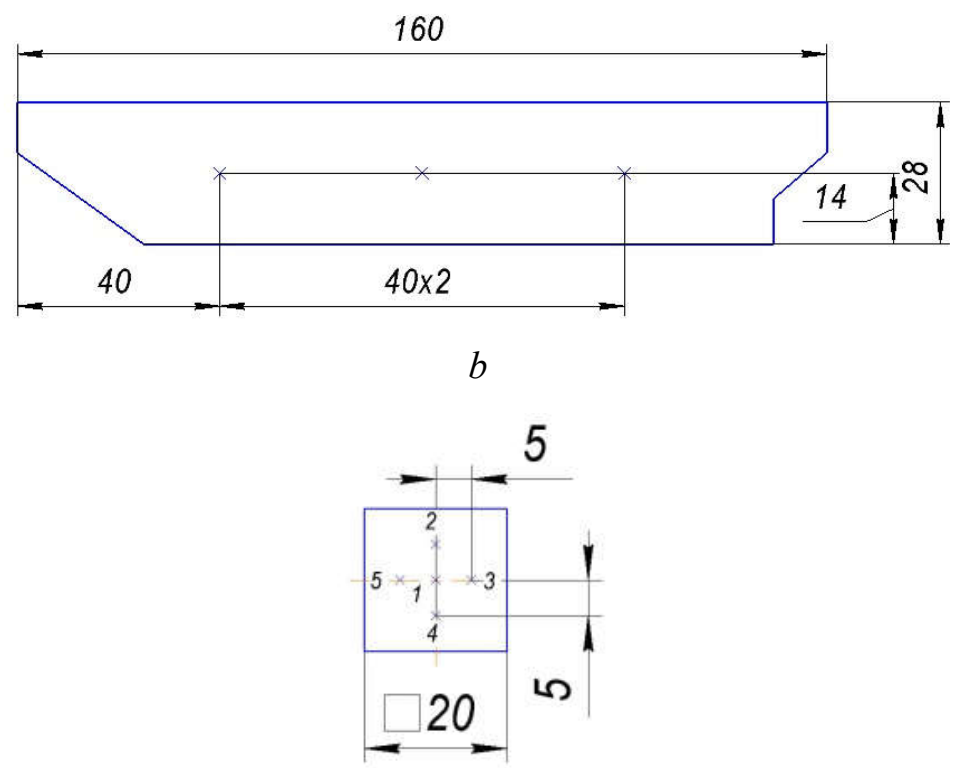

$c$

Figure 2. Points for determining the $\mathrm{OH}$ value of the surface layer: points on the surface of samples from VZhL14-BM (a); points on the surface of a specimen from VZhM-4 (b); diagram of the location of points on the run-in area $(c)$

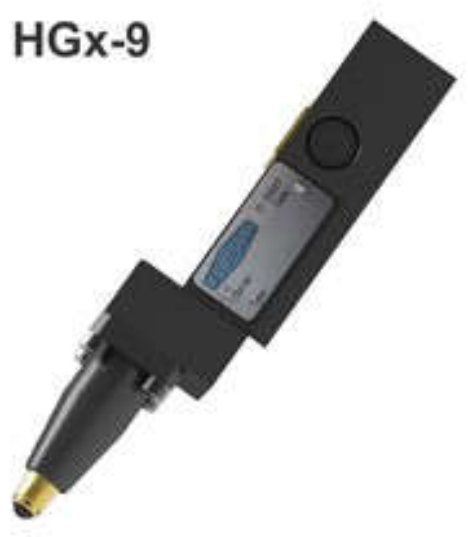

Figure 3. Hydrostatic tool HG6-9_SL (K) from Ecoroll

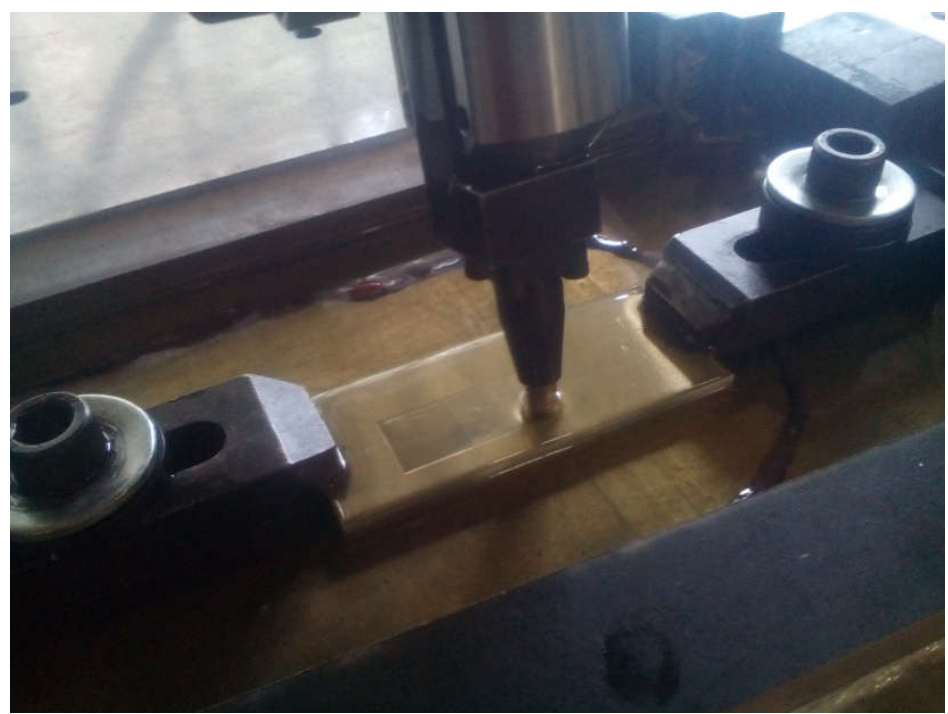

Figure 4. Scheme of fixing the sample

Table 3. Knurling modes on sample No. 1

\begin{tabular}{c|c|c|c}
\hline Mode No. & Effort, $\mathbf{k g f}$ & Step, $\mathbf{m m}$ & Speed, $\mathbf{m m} / \mathbf{m i n}$ \\
\hline 1 & 100 & & \multirow{2}{*}{0.1} \\
\cline { 1 - 2 } 2 & 75 & & 500 \\
\hline 3 & 50 & & \\
\hline
\end{tabular}


"Instrumentation Engineering, Electronics and Telecommunications - 2018"

Proceedings of the IV International Forum (Izhevsk, Russia, December, 12-14, 2018)

Table 4. Knurling modes on sample No. 2

\begin{tabular}{c|c|c|c|c}
\hline Mode No. & Effort, $\mathbf{k g f}$ & Step, $\mathbf{m m}$ & Speed, $\mathbf{m m} / \mathbf{m i n}$ & Direction of processing \\
\hline \multirow{2}{*}{75} & \multirow{2}{*}{75} & 0.2 & 500 & $0^{\circ}$ \\
\cline { 4 - 5 } \cline { 4 - 5 } & & 0.05 & 1000 & Mesh \\
\hline 6 & & & & $0^{\circ}$ \\
\hline
\end{tabular}

Table 5. Knurling modes on sample No. 3

\begin{tabular}{c|c|c|c|c}
\hline Mode No. & Effort, $\mathbf{k g f}$ & Step, $\mathbf{m m}$ & Speed, $\mathbf{m m} / \mathbf{m i n}$ & Direction of processing \\
\cline { 1 - 2 } 1 & \multirow{2}{*}{75} & 0.2 & \multirow{2}{*}{500} & $0^{\circ}$ \\
\cline { 1 - 1 } 2 & & 0.05 & & Mesh \\
\cline { 1 - 1 } 3 & & & & $0^{\circ}$ \\
\hline
\end{tabular}

RESULTS AND DISCUSSION

Samples after hardening rolling

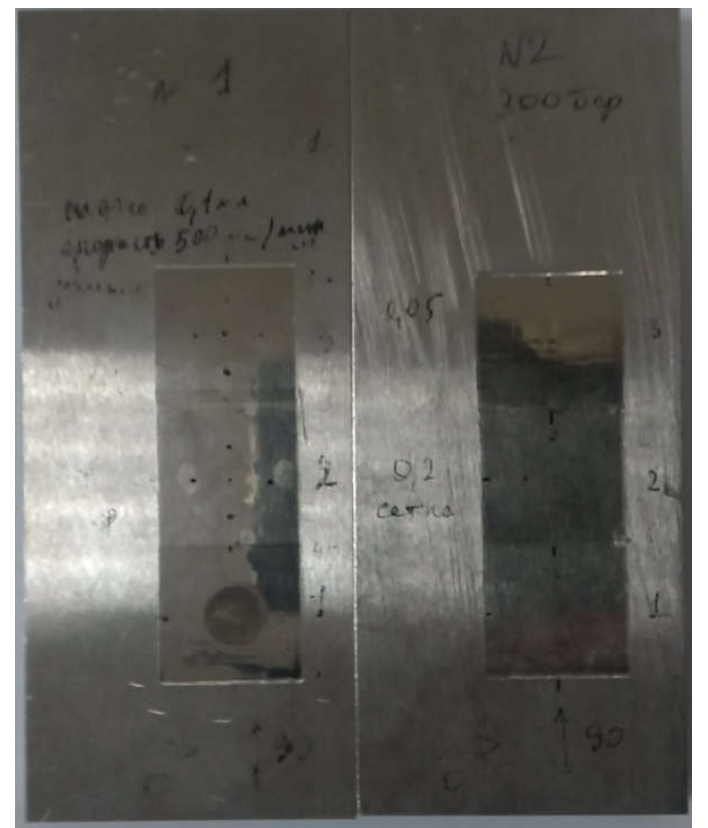

$a$

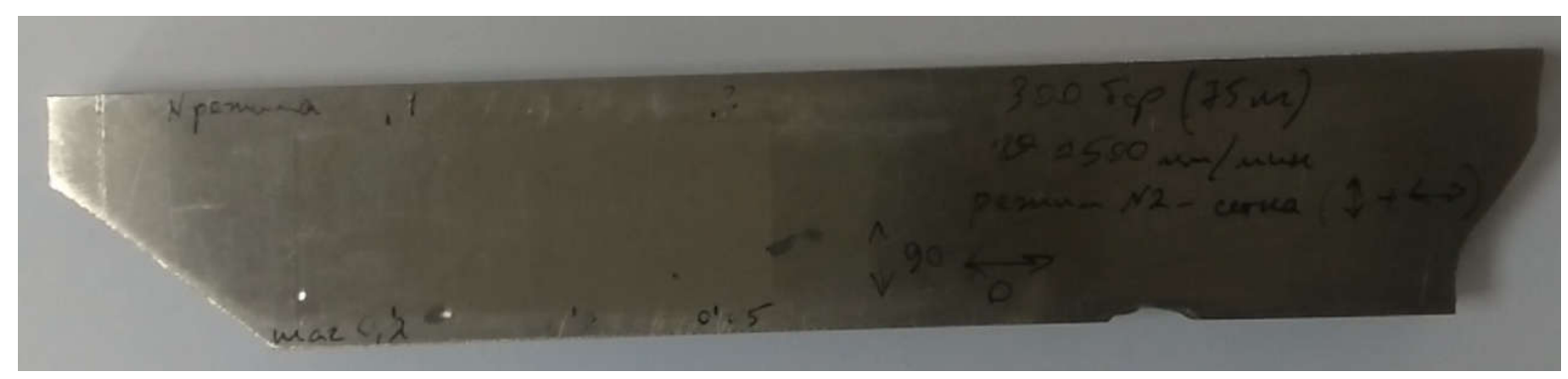

$b$

Figure 5. Samples after hardening rolling: No. 1-2 (a); No. $3(b)$ 


\section{Residual stresses}

The location of the monitoring object in the Xstress Robot X-ray diffractometer chamber with the directions of measurement is shown in Figures 6-7.

Graphs of RS distribution in the surface layer prior to rolling are presented in Figure 8.

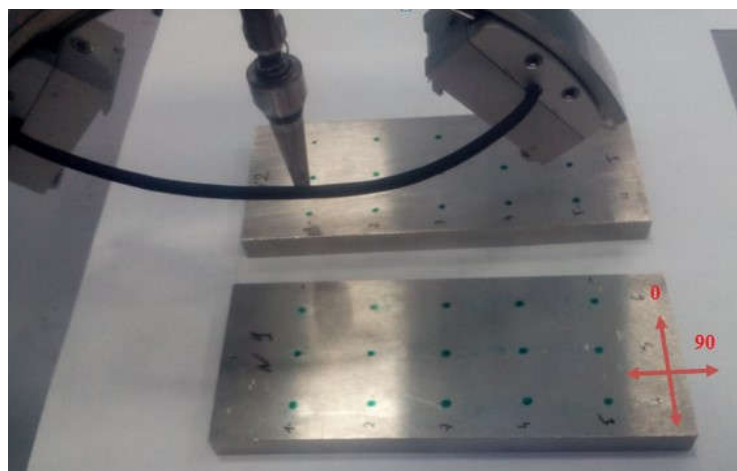

$a$

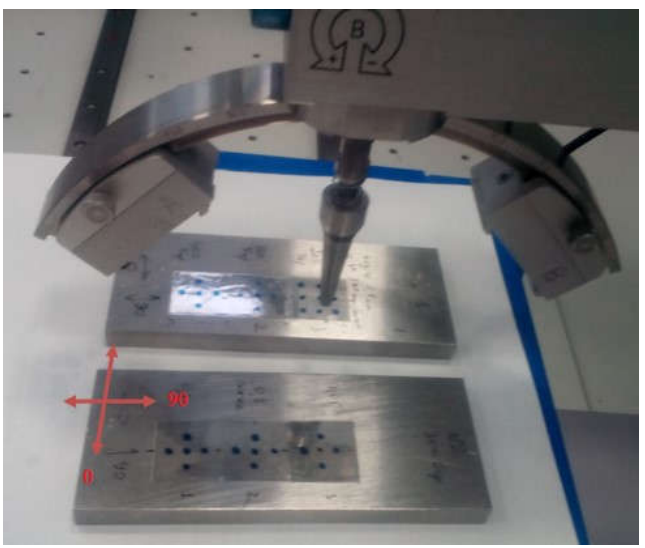

$b$

Figure 6. Location of samples No. 1-2 in the diffractometer chamber: before processing $(a)$; after treatment $(b) ; 90^{\circ}$ - transverse direction (perpendicular to the movement of the instrument); $0^{\circ}$ - longitudinal direction (along the axis of the tool movement)

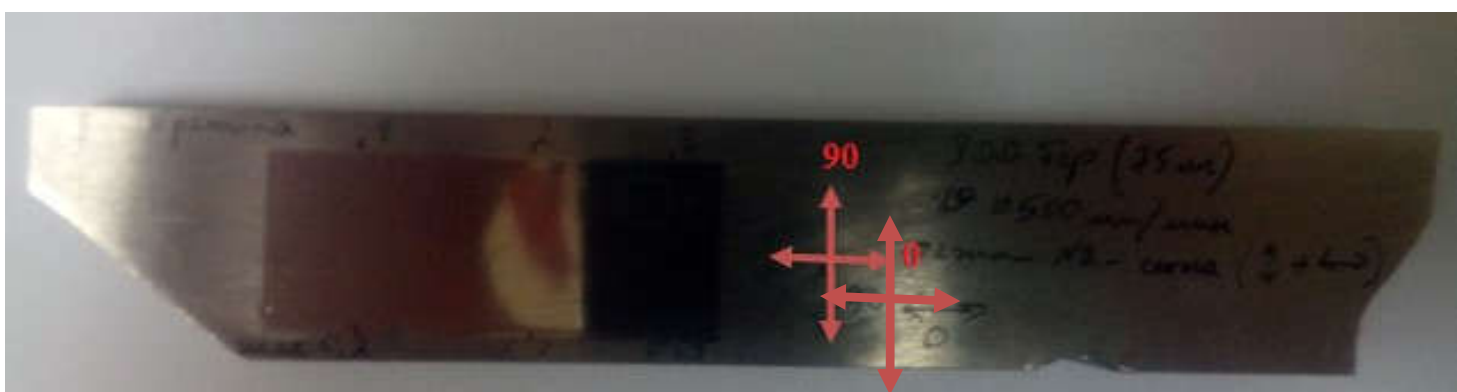

Figure 7. The location of sample No. 3 in the diffractometer chamber: $90^{\circ}$ - longitudinal direction (along the axis of the tool movement); $0^{\circ}$ - transverse direction (perpendicular to the movement of the tool)

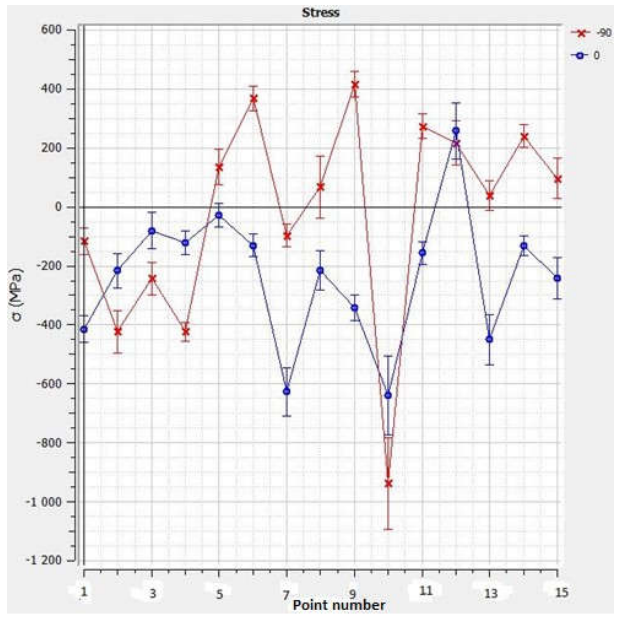

$a$

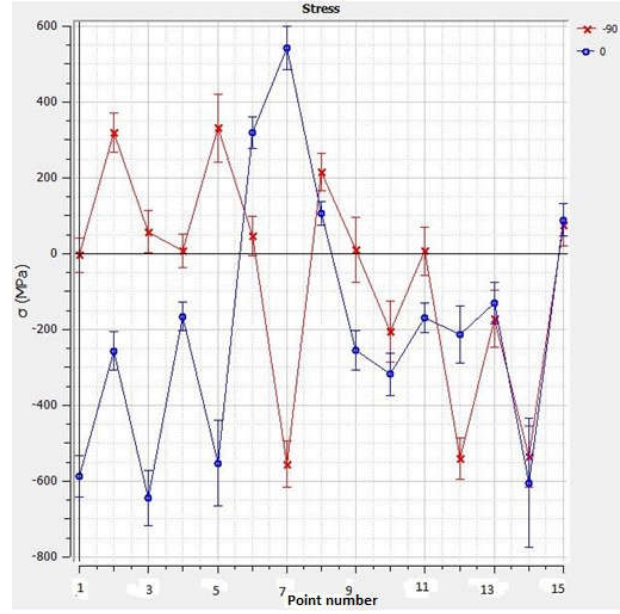

$b$

Figure 8. The distribution of RS on the surface of samples from VZhL14: No. 1 (a); No. $2(b)$ 
"Instrumentation Engineering, Electronics and Telecommunications - 2018"

Proceedings of the IV International Forum (Izhevsk, Russia, December, 12-14, 2018)

Graphs of RS distribution in the surface layer of the alloy VZhL14-VM after rolling are shown in Figure 9.

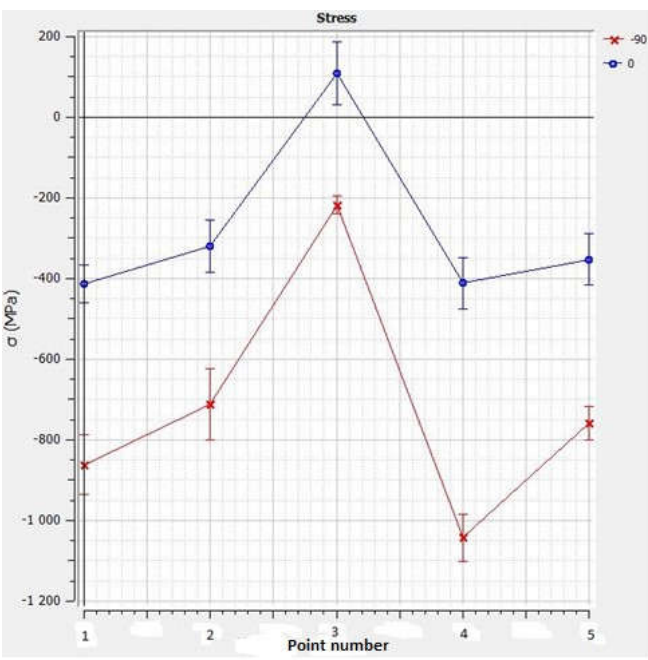

$a$
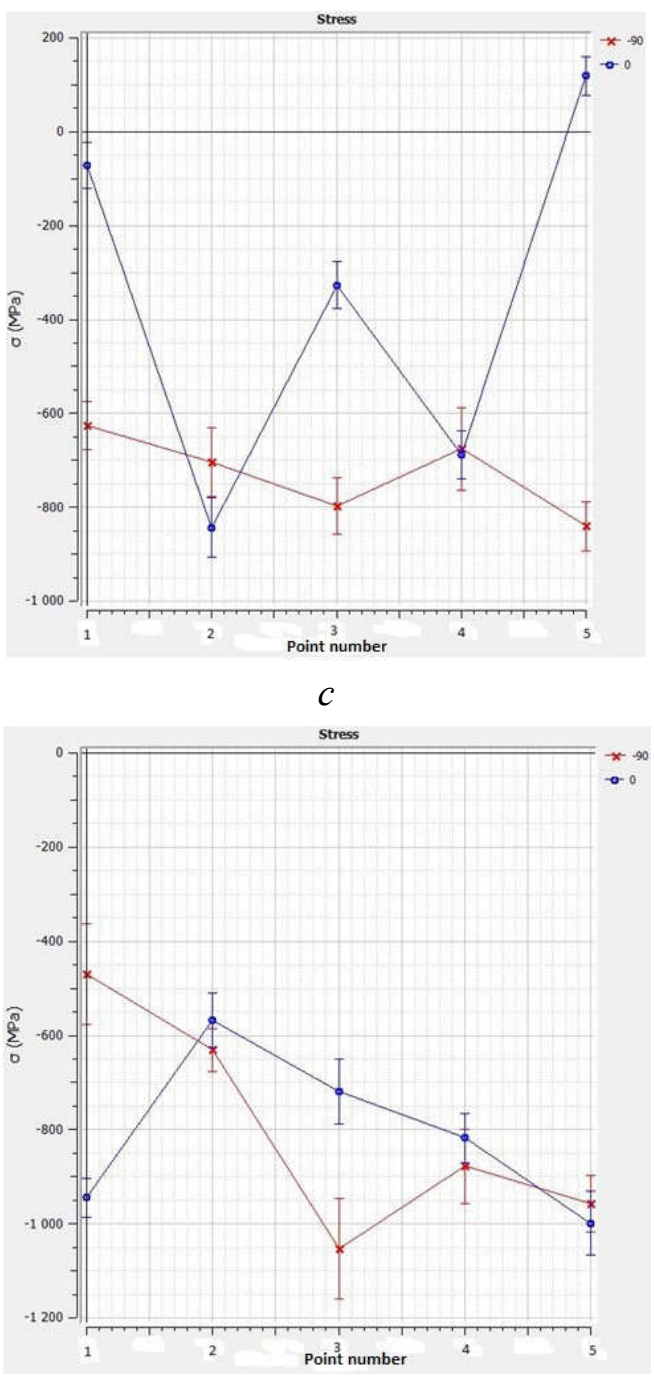

$e$

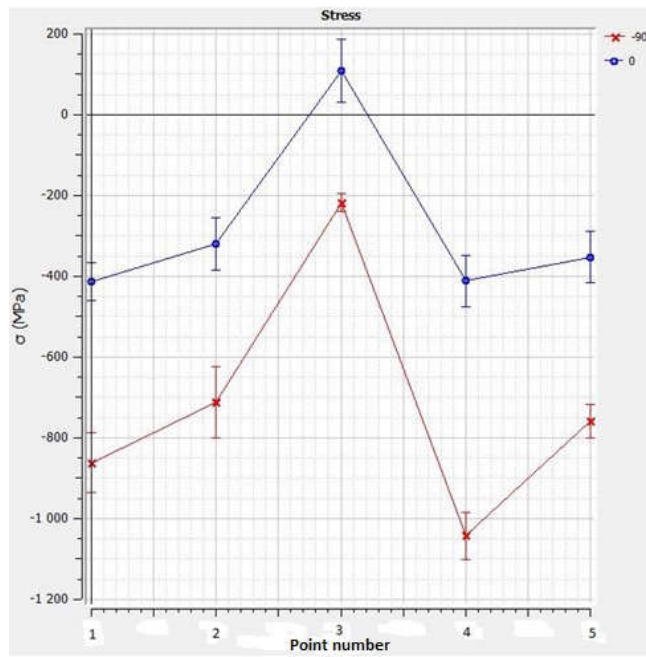

$b$

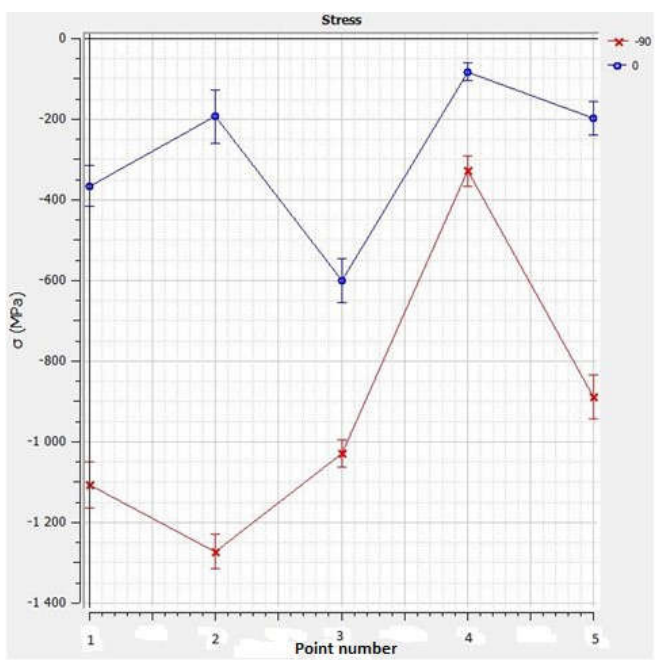

$d$

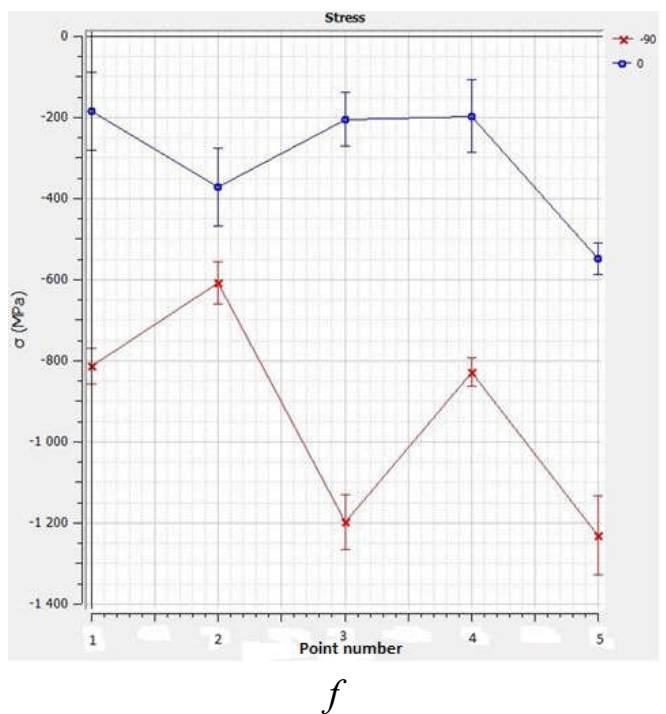

Figure 9. The distribution of RS on the surface of samples No. 1-2:

mode No. $1(a)$; mode No. $2(b)$; mode No. $3(c)$; mode No. $4(d)$; mode No. $5(e)$; mode No. $6(f)$ 
Graphs of OH distribution in the surface layer of sample No. 3 (VZhM-4) after rolling are shown in Figure 10.
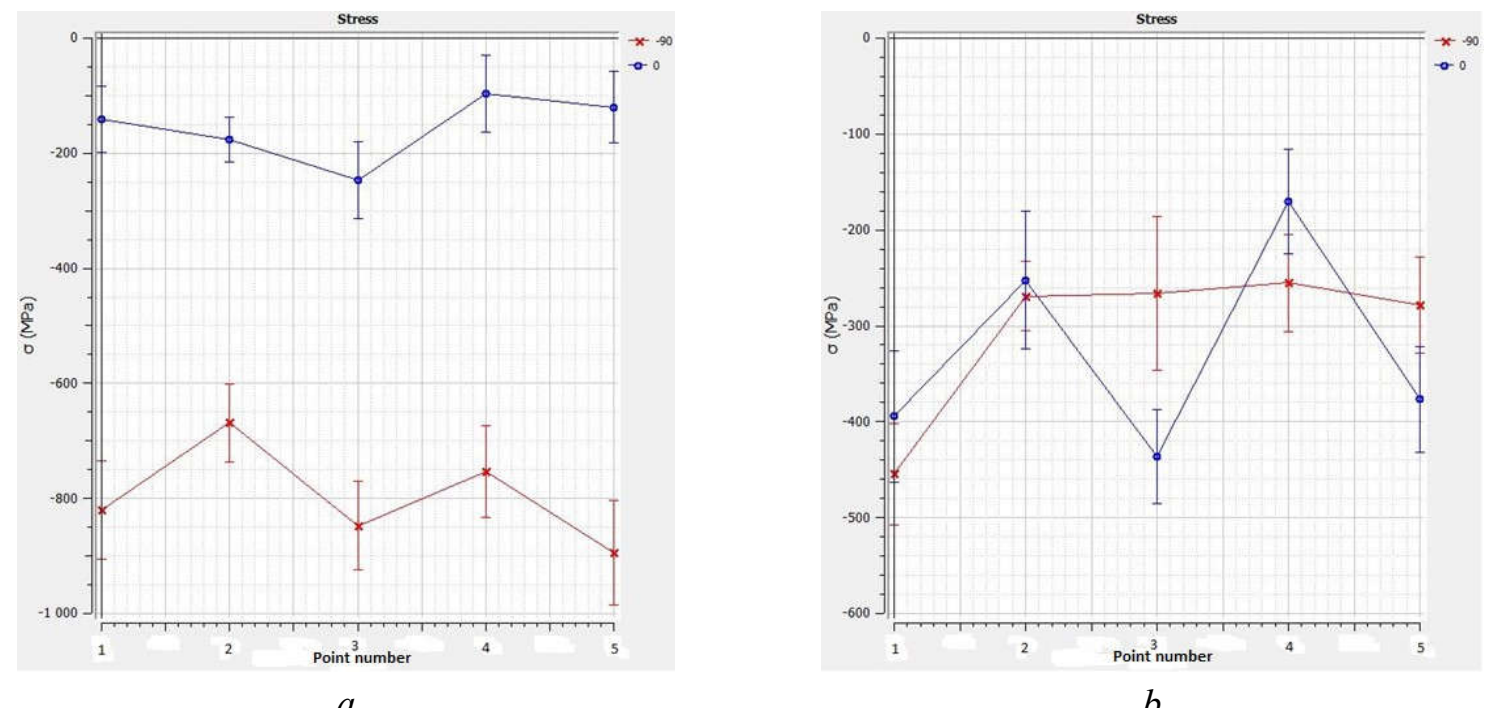

$a$

$b$

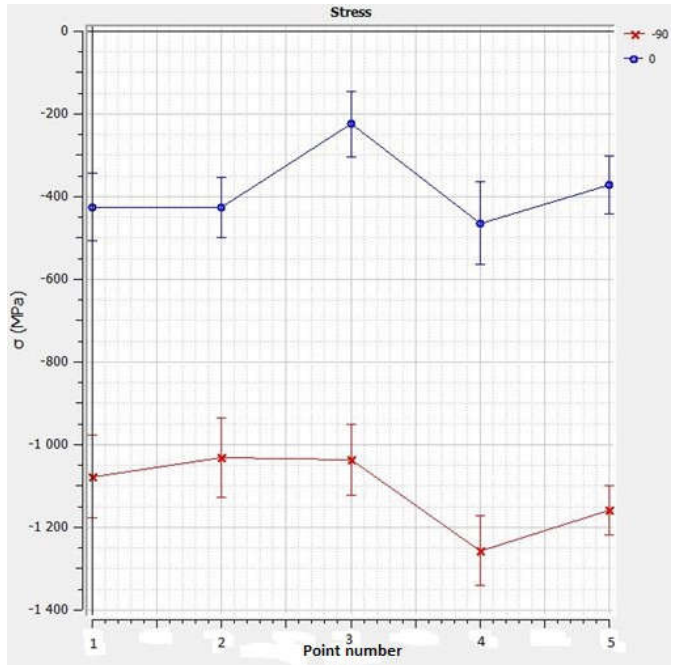

$c$

Figure 10. The distribution of RS on the surface of samples No. 3: mode No. 1 (a); mode No. 2 (b); mode No. 3 (c)

\section{Depth of crumple of the surface layer}

The depth of the crushing of the layer was measured as the average value over 9 points.

\section{Roughness}

The values of $\mathrm{Ra}$ are the average of 5 measurements (Table 7 ), where $0^{\circ}$ is a direction along the axis of movement of the tool $(\mathrm{VZhL}) ; 90^{\circ}$ is a direction perpendicular to the axis of movement of the tool (VZhL). For sample No. 3 (VZhM-4), the values are opposite.

For Mode 4 , the roughness $\left(0^{\circ}\right)$ varies over a wide range of $0.129-0.621 \mu \mathrm{m}$. This is due to the large step $(0.2 \mathrm{~mm})$ during processing, because the larger value of Ra corresponds to the crest between the depressions. 
"Instrumentation Engineering, Electronics and Telecommunications - 2018"

Proceedings of the IV International Forum (Izhevsk, Russia, December, 12-14, 2018)

Table 6. The results of the measurement of the depth of crushing of the surface layer upon rolling

\begin{tabular}{|c|c|c|c|}
\hline Material & Sample No. & Mode No. & Depth of layer crushing, $\mu \mathrm{m}$ \\
\hline \multirow{6}{*}{ VZhL14-VM } & \multirow{3}{*}{1} & 1 & 12 \\
\hline & & 2 & 12 \\
\hline & & 3 & 7 \\
\hline & \multirow{3}{*}{2} & 4 & 14 \\
\hline & & 5 & 14 \\
\hline & & 6 & 9 \\
\hline \multirow{3}{*}{ VZhM-4 } & \multirow{3}{*}{3} & 1 & 3 \\
\hline & & 2 & 3 \\
\hline & & 3 & 2 \\
\hline
\end{tabular}

Table 7. Results of measuring the roughness of samples

\begin{tabular}{|c|c|c|c|c|}
\hline Material & Sample No. & Mode No. & $\operatorname{Ra}, \mu \mathrm{m}\left(0^{\circ}\right)$ & Ra, $\mu \mathrm{m}\left(90^{\circ}\right)$ \\
\hline \multirow{8}{*}{ VZhL14-VM } & \multirow{4}{*}{1} & Before processing & 0.768 & 0.359 \\
\hline & & 1 & 0.142 & 0.156 \\
\hline & & 2 & 0.178 & 0.186 \\
\hline & & 3 & 0.167 & 0.175 \\
\hline & \multirow{4}{*}{2} & Before processing & 0.757 & 0.265 \\
\hline & & 4 & 0.351 & 0.265 \\
\hline & & 5 & 0.362 & 0.122 \\
\hline & & 6 & 0.281 & 0.249 \\
\hline \multirow{4}{*}{ VZhM-4 } & \multirow{4}{*}{3} & Before processing & 0.406 & 0.629 \\
\hline & & 1 & 0.090 & 0.522 \\
\hline & & 2 & 0.141 & 0.096 \\
\hline & & 3 & 0.052 & 0.108 \\
\hline
\end{tabular}

\section{Microhardness}

The HV values are obtained as an average of 5 points.

Table 8. Results of measuring the roughness of samples

\begin{tabular}{|c|c|c|c|}
\hline Material & Sample No. & Mode No. & HV \\
\hline \multirow{8}{*}{ VZhL14-VM } & \multirow{4}{*}{1} & Before processing & 322.93 \\
\hline & & 1 & 488.70 \\
\hline & & 2 & 489.73 \\
\hline & & 3 & 483.38 \\
\hline & \multirow{4}{*}{2} & Before processing & 346.65 \\
\hline & & 4 & 469.79 \\
\hline & & 5 & 508.12 \\
\hline & & 6 & 473.42 \\
\hline \multirow{4}{*}{ VZhM-4 } & \multirow{4}{*}{3} & Before processing & 435.52 \\
\hline & & 1 & 576.08 \\
\hline & & 2 & 609.68 \\
\hline & & 3 & 619.36 \\
\hline
\end{tabular}


The reinforcing rolling leads to an increase in the microhardness of the surface by $25-33 \%$. The value of HV for the alloy VZhL14-VM is not affected by the pressure and processing step. The microhardness is affected by the rolling pattern.

For the alloy VZhM-4, the value of HV depends on the rolling pattern and the pitch.

\section{CONCLUSIONS}

The results of the study showed that:

- for all samples and processing modes, strengthening knurling leads to the formation of squeezing $\mathrm{OH}$ and equalization of their values, and also virtually eliminates stretching $\mathrm{OH}$;

- the depth of the crushing of the surface layer depends on the rolling force and is comparable to the tolerances for the manufacture of engineering parts, which does not lead to a significant distortion of their geometry;

- microhardness of the surface of the samples, depending on the regimes of hardening rolling, increases by $25-33 \%$;

- the roughness depends on the rolling force, the processing step, the rolling pattern and leads to a 2-fold or more decrease in the Ra parameter.

The results of the work show that the reinforcing rolling has a positive effect on the properties of the surface layers of the samples and this technology can be used for finishing the parts made of high-temperature alloys of the VZhL14-VM and VZhM-4 grades.

\section{REFERENCES}

1. Podzey, A. V. (1973). Tekhnologicheskiye ostatochnyye napryazheniya [Technological residual stresses]. Moscow, USSR : Mashinostroenie (in Russian).

2. Blyumenshtein, V. Yu., \& Smelyanskiy, V. M. (2007). Mekhanika tekhnologicheskogo nasledovaniya na stadiyah obrabotki $i$ ekspluatatsii mashin [Technological inheritance mechanics at stages of machine parts machining and operation]. Moscow, Russia : Mashinostroenie (in Russian).

3. Zaides, S. A., \& Ngo, C. C. (2018). The influence of new kinematics of the rolling roller on the quality of the hardened layer under surface plastic deformation. Proceedings of Higher Educational Institutions. Machine Building, 2(695), 58-67. doi: 10.18698/0536-1044-2018-2-58-67 (in Russian).

4. Zaides, S. A., \& Ngo, C. C. (2017). New technological potentialities of finish-strengthening by surface plastic deformation. Science Intensive Technologies in Mechanical Engineering, 2(3), 25-30. doi: $10.12737 / 24961$ (in Russian).

5. Zaides, S. A., \& Ngo, C. C. (2017). Increasing the stress state in the deformation zone for cylindrical parts under surface plastic deformation. Proceedings of Higher Educational Institutions. Machine Building, 5(686), 52-59. doi: 10.18698/0536-1044-2017-5-52-59 (in Russian).

6. Gorohov, V. A. (1975). Chistovaya obrabotka titanovyh splavov [Finishing of titanium alloys]. Moscow, USSR : Mashinostroenie (in Russian).

7. Gorohov, V. A., \& Spiridonov, N. V. (2003). Sposoby otdelochno-uprochnyayushchey obrabotki materialov [Methods of finishing-strengthening processing of materials]. Minsk, Belarus : Tekhnoprint (in Russian).

8. Gorohov, V. A. (1978). Obrabotka detaley plasticheskim deformirovaniyem [Processing of parts by plastic deformation]. Kiev, USSR : Tekhnika (in Russian).

9. Papshev, D. D. (1968). Uprochneniye detaley obkatkoy sharikami [Hardening of details by rolling balls]. Moscow, USSR : Mashinostroenie (in Russian).

10. Hamadache, H., Zemouri, Z., Laounar, L., \& Dominiak, S. (2014). Improvement of surface conditions of $36 \mathrm{Cr}$ Ni Mo 6 steel by ball burnishing process. Journal of Mechanical Science and Technology, 28(4), 1491-1498. doi: 10.1007/s12206-014-0135-1. 
"Instrumentation Engineering, Electronics and Telecommunications - 2018"

Proceedings of the IV International Forum (Izhevsk, Russia, December, 12-14, 2018)

11. Mohammadi, F., Sedaghati, R., \& Bonakdar, A. (2014). Finite element analysis and design optimization of low plasticity burnishing process. The International Journal of Advanced Manufacturing Technology, 70(5-8), 1337-1354. doi: 10.1007/s00170-013-5406-y.

12. Rao, D. S., Hebbar, H. S., Komaraiah, M., \& Kempaiah, U. N. (2008). Investigations on the effect of ball burnishing parameters on surface hardness and wear resistance of HSLA dual-phase steels. Materials and Manufacturing Processes, 23(3), 295-302. doi: 10.1080/10426910801937306.

13. Loll, N. H., Tam, S. C., \& Miyazawa, S. (1991). Investigations on the surface roughness produced by ball burnishing. International Journal of Machine Tools and Manufacture, 31(1), 75-81. doi: 10.1016/08906955(91)90052-5.

14. El-Axir, M. H. (2000). An investigation into roller burnishing. International Journal of Machine Tools and Manufacture, 40(11), 1603-1617. doi: 10.1016/S0890-6955(00)00019-5.

15. El-Taweel, T. A., \& El-Axir, M. H. (2009). Analysis and optimization of the ball burnishing process through the Taguchi technique. The International Journal of Advanced Manufacturing Technology, 41(3-4), 301-310. doi: 10.1007/s00170-008-1485-6.

16. Klocke, F., Bäcker, V., Wegner, H., Feldhaus, B., Baron, H. U., \& Hessert, R. (2009). Influence of process and geometry parameters on the surface layer state after roller burnishing of IN718. Production Engineering, 3(4), 391-399. doi: 10.1007/s11740-009-0182-0.

17. Golden, P. J., \& Shepard, M. J. (2007). Life prediction of fretting fatigue with advanced surface treatments. Materials Science and Engineering: A, 468-470, 15-22. doi: 10.1016/j.msea.2006.10.168.

18. Laouar, L., Hamadache, H., Saad, S., Bouchelaghem, A., \& Mekhilef, S. (2009). Mechanical surface treatment of steel. Optimization parameters of regime. Physics Procedia, 2(3), 1213-1221. doi: 10.1016/j.phpro. 2009.11.084.

19. Luca, L., Neagu-Ventzel, S., \& Marinescu, L. (2005). Effects of working parameters on surface finish in ballburnishing of hardened steels. Precision Engineering, 29(2), 253-256. doi: 10.1016/j.precisioneng.2004. 02.002 . 